\title{
Rafal Milan \\ Dotyk metafory. O metapoetyckich aspektach dotyku (głównie) w Sadzie rozstajnym Bolesława Leśmiana
}

\begin{abstract}
The Touch of Metaphor. On Metapoetic Aspects of Touch (Mainly) in Sad rozstajny (Bifurcated Orchard) by Bolesław Leśmian

The text is an attempt to widen the study field dealing with the senses in the world implied by the poetry of Bolesław Leśmian by including the so far neglected aspect of the essential role of touch in creating this world. The metapoetic reflection, inscribed in poems coming mainly from Leśmian's first volume and being often the source and part of their plot, suggests the integral relation between the process of metaphorization (or, process of realizing a metaphor) and acting through touch in the presented reality. Thus understood, touch does not, however, constitute a simple metaphor of a creative act; rather, it problematizes the very (im)possibility of going beyond the "tangible" materiality of the text.

The interpretations carried out make it possible to visualize a specific - poetic modality of touch, which is close to caress - as defined by Lévinas. In the face of the literary "reflexiveness" of that sense, the poem touches upon the non-literary reality like a shadow portending that which is not yet present.
\end{abstract}

Słowa kluczowe: Bolesław Leśmian, język poezji nowoczesnej, metafora, dotyk, sensualność literatury

Keywords: Bolesław Leśmian, language of modern poetry, metaphor, touch, sensuality of literature 
Bo i mnie też pęta

Żądza przebycia nad strumieni wodą Nagłego lasu, co złudnie się spiętrza, Ale nie mogę wejść cały do wnętrza Mego snu: jestem sam sobie przegrodą. Choć w nim się błąkam, choć dłońmi obiema Dotykam kwiatów, wiem, że mnie tam nie ma.

B. Leśmian, Sen wiejski [podkreśl. moje - R.M.]

W książce poświęconej cielesności i dotykowi w polskiej poezji współczesnej Beata Przymuszała sugeruje, iż ciało - i jego poetycka reprezentacja nie powinny stanowić (jedynie) przedmiotu literaturoznawczego namysłu. Innymi słowy: sprowadzenie tego, co presymboliczne, do rangi jednego z literackich tematów, uchwytnych za pomocą tradycyjnych filologicznych narzędzi, byłoby zaledwie powieleniem opresji, jakiej poddana jest somatyczność (a także - jak postaram się dowieść - literacka materialność) w racjo- i wzrokocentrycznej kulturze. Przymuszała, odwołując się do fragmentu Nieobjętej ziemi Czesława Miłosza, proponuje zatem spojrzenie na literaturę w perspektywie jej ,nieprzechodnich” aspektów:

Zwraca on [Miłosz - R.M.] wszak uwagę na cielesność samej poezji, która powinna odzwierciedlać powiązanie między ludzką fizycznością a twórczością rytm ciała ma stać się rytmem wiersza, niekoniecznie jednak metrycznym (w sensie matematycznego uporządkowania). Tak pojmowana somatyzacja wymaga zmiany zarówno myślenia o człowieku, jak i rozumienia literatury ${ }^{1}$.

Co dla mnie szczególnie istotne, badaczka dostrzega w twórczości Bolesława Leśmiana rozwiązania prekursorskie wobec rozpatrywanych przez nią dokładniej powojennych prób poetyckiego mówienia o ciele i - zarazem „ucieleśniania” samej poezji. Jako wartościowy kontekst interpretacyjny dla poezji autora Sadu rozstajnego przywołuje filozofię dialogu ,z jej niezwykle mocnym akcentowaniem somatyczności"². Twórczość Leśmiana - zdaniem autorki - nadal zależna jest jednak od myślenia o świecie w kategorii opozycji podmiotu i przedmiotu; dopiero bowiem w poezji powojennej następuje „przeniesienie punktu ciężkości z sensualnego aspektu ciała (podkreślającego jednak przede wszystkim odczuwanie jednostki) na eksponowanie dotyku jako elementu budowania relacji"'s.

1 B. Przymuszała, Szukanie dotyku: problematyka ciała w polskiej poezji współczesnej, Kraków 2006, s. 6. Przymuszała odwołuje się do następującego fragmentu: „Jaka będzie poezja w przyszłości, ta, o której myślę, ale której już nie poznam? Wiem, że jest możliwa, bo znam krótkie chwile, kiedy już niemalże tworzyła się pod moim piórem, żeby zaraz zniknąć. Rytmy ciała - bicie serca, puls, pocenie się, krwawienie periodu, lepkość spermy, pozycja przy oddawaniu moczu, ruch kiszek, będą w niej zawsze obecne razem z podniosłymi potrzebami ducha i nasza podwójność znajdzie swoją formę bez wyrzekania się jednej strefy albo drugiej”. Cyt. za: Cz. Miłosz, Wiersze wszystkie, Kraków 2011, s. 802.

2 B. Przymuszała, op.cit., s. 368.

3 Ibidem. 
W dalszych rozważaniach, skupionych wokół problemu interakcji wzroku i dotyku w poemacie Zielona godzina i innych - traktowanych jako kontekst - wierszach z Sadu rozstajnego, zamierzam podążać za tą intuicją interpretacyjną, traktującą twórczość Leśmiana jako inspirację do przemyślenia poezji (tej konkretnej, ale i poezji „w ogóle”) w perspektywie jej specyficznej cielesności. Trudno mi jednak przystać na zredukowanie roli dotyku w poetyckim świecie Leśmiana do aspektu czysto sensualnego czy wrażeniowego. Logiczną konsekwencją takiego ujęcia byłoby bowiem rozpatrywanie tego zmysłu w kontekście na wskroś „,sensualistycznej epistemologii” Leśmiana ${ }^{4}$, ufundowanej na wpisanych w jego poezję ontologicznych założeniach. Dotyk - czy szerzej: ciało i zmysły - zostałby zatem umieszczony wśród istotnych „tematów", oświetlających jedynie pewien aspekt ukonstytuowanej w języku rzeczywistości. Sformułuję rzecz radykalniej: mówienie o cielesności (w) poezji (Leśmiana) - jeśli ma być czymś więcej niż „tylko porównaniem” - powinno zakładać faktyczny udział ciała, czy inaczej mówiąc: „, ucieleśnionych” zmysłów, zwłaszcza zaś dotyku jako zmysłu ,spacjalnego", bliższego ciału w akcie tworzenia owej poetyckiej rzeczywistości.

Jak miałaby jednak przejawiać się owa „faktyczność”? Jakie warunki powinny być spełnione, by móc mówić o taktylności poezji? Jak rozumieć swoiste naznaczenie poezji przez dotyk? Czy mielibyśmy do czynienia z jego specyficzną - „poetycką" - modalnością? Ambicją poniższych fragmentów analityczno-interpretacyjnych jest próba zarysowania wstępnych odpowiedzi na tak sformułowane pytania ${ }^{5}$.

Dogodny punkt wyjścia do dalszych rozważań stanowi - jak sądzę - inicjalna strofa wiersza Zamyślenie:

Kto wybaczy mi moją do wróżby niezdolność?

Nie wiem, co dziś pokocham, co jutro wyśpiewam?

I dłonią, jak sierść zwierza, głaszczę mimowolność

Pieśni, których warczenia w sobie się spodziewam ${ }^{6}$.

4 Zob. Z. Łapiński, Metafizyka Leśmiana [w:] Studia o Leśmianie, red. M. Głowiński, J. Sławiński, Warszawa 1971, s. 41 i n.

5 W niniejszym tekście podejmuję zatem problem analogiczny do prób opisu relacji „między ciałem a literacką figuratywnością, rytmem, metaforą, narracją, przestrzenią, tekstem literackim”, a także „między kategorią cielesności a poetyką”. Zob. A. Łebkowska, Jak ucieleśnić ciało: o jednym z dylematów somatopoetyki, „Teksty Drugie” 2014, nr 4, s. 12. Proponuję natomiast ujęcie materialności czy też sensualności tekstu literackiego w innej perspektywie, niż czyni to Adam Dziadek, który koncentruje się na udziale bardziej oczywistych w wypadku literatury zmysłów - wzroku i słuchu - w nadawaniu tekstowi jednostkowej sygnatury, powtarzanej w cielesno-zmysłowej recepcji. Zob. np. A. Dziadek, Projekt krytyki somatycznej, Warszawa 2014.

6 B. Leśmian, Poezje zebrane, Warszawa 2010, s. 276. Wiersze Leśmiana każdorazowo cytuję na podstawie tego wydania. Dalej w tekście posługuję się skrótem PZ i podaję numer stron(y), na których/-ej znajduje się cytowany fragment. 
W perspektywie interpretacji Zielonej godziny (i wierszy bezpośrednio ją poprzedzających w tomie Sad rozstajny) poznawczo wartościowe wydaje mi się wyeksponowanie pomijanego przez dotychczasowych interpretatorów $Z a$ myślenia włączenia zmysłu dotyku w obręb refleksji metapoetyckiej’. Szczególnie istotny jest sposób, w jaki owo włączenie się odbywa. Dwa pierwsze wersy wprowadzają wątek niewiedzy, dotyczącej przyszłości: tej bliższej (co dziś pokocham?) i nieco dalszej (co jutro wyśpiewam?). Wiersz sugeruje być może splot antycypowanej miłości i śpiewu. Trudno rozstrzygnąć, czy to, co dziś pokocham, jutro wyśpiewam - nic nie uniemożliwia jednak takiego odczytania. Nie ulega natomiast wątpliwości, że „przedmiot” uczucia i tworzenia pozostaje nieznany: jest więc tak, jak gdyby energia zapowiedzi, czy też energia przejawiająca się w zapowiedzi, stanowiła otwarcie na przyszłość niepodlegającą władzy podmiotu, tak bowiem rozumiem „do wróżby niezdolność" $\mathrm{z}$ inicjalnego wersu.

Należy podkreślić, iż wspomniane - nieredukowalne do uprzedniej określonej intencji - wychylenie ku przyszłości zostało w wierszu wprowadzone przez odniesienie do zmysłu dotyku (w. 3-4). To jednak dotyk nad wyraz osobliwy. Pieszczotliwie dotyka bowiem tego, czego - logicznie rzecz ujmując - jeszcze nie ma, tj. „mimowolnoś[ci] / Pieśni, których warczenia w sobie się spodziewam”. Co godne uwagi, sposób głaskania (,jak sierść zwierza”)

7 W klasycznym szkicu poświęconym wpisanej w poezję Leśmiana refleksji metapoetyckiej Michał Głowiński nie wspomina o potencjalnie „samozwrotnej” funkcji dotyku. Repertuar figur metapoetyckich ogranicza badacz, odwołując się do poglądów na poezję sformułowanych wprost $\mathrm{w}$ eseistyce poety (co prowadzi do uprzywilejowania zmysłu słuchu i wzroku, kulminującego w jednoznacznej interpretacji metafory ,widzenia poprzez śpiew”). Zob. M. Głowiński, Słowo i pieśń (Leśmiana poezja o poezji) [w:] idem, Zaświat przedstawiony. Szkice o poezji Bolesława Leśmiana, Kraków 1998. Najbardziej w ostatnich latach wpływowe odczytanie Zamyślenia rozwija (i nieco modyfikuje) ustalenia Głowińskiego. Komentując wątek wyglądania w świat poprzez śpiew, „słowami”, Ryszard Nycz uogólnia Leśmianowskie przeświadczenia dotyczące możliwości i zadań poezji: „Sztuka poetycka jest tu teraz rozumiana jako twórcza praca w słowach, dzięki której «wyglądy» słowa stają się «postaciami» świata, a język poetycki - tajemniczym darem wynajdującym formy realności; sposobem odkrywania niedostępnych na co dzień «wyglądów» rzeczywistości”. Zob. R. Nycz, ,, Stowami... w świat wygladam”. Bolestawa Leśmiana poezja nowoczesna [w:] idem, Literatura jako trop rzeczywistości. Poetyka epifanii w nowoczesnej literaturze polskiej, Kraków 2012, s. 124. Jak sądzę, zwrócenie uwagi na odwołania do zmysłu dotyku w refleksji metapoetyckiej Leśmiana (na myślenie o poezji w paradygmacie dotyku) pozwoli przekonująco wskazać aspekty świadomości poety, niemieszczące się w jej obrazie, ukształtowanym przez wyżej wymienionych badaczy (tzn. nieuchronnie marginalizowane w perspektywach odpowiednio: mitu poety jako człowieka pierwotnego oraz założenia o inwencyjno-poznawczym charakterze poezji nowoczesnej). Dotychczasowa polemika z koncepcją Nycza opierała się na próbach wartościującego przeciwstawienia „pieśni bez słów” i jej werbalnej konkretyzacji. Zob. J. Zięba, Pieniadz i słowo. Nowoczesne paradoksy Leśmianowskiego języka poetyckiego, „Teksty Drugie” 2010, nr 6; E. Winiecka, Z wnętrza dystansu. Leśmian - Karpowicz Białoszewski - Miłobędzka, Poznań 2012. 
niejako udziela się jego antycypowanemu „obiektowi” (podmiot spodziewa się warczenia, następnie relacjonuje: „Po warczeniu poznaję, że przybyły z lasów") ${ }^{8}$. Innymi słowy: mamy tu do czynienia z przeniesieniem - na zasadzie figury hypallage - sposobu ujęcia na właściwość tego, co ujmowane. Jak się wydaje, czynność manualna nie daje się w Zamyśleniu sprowadzić do funkcji sensualnej metafory procesu twórczego. Trafniej byłoby - jak sądzę - powiedzieć, że dotyk metaforyzuje tu samą metaforę, która zostaje ze wspomnianym zmysłem integralnie połączona.

Można by to sformułować jeszcze inaczej: mechanizm stwarzający samą możliwość wiersza jest w analizowanym utworze tożsamy ze swoistym „podwojeniem” metafory. Jej część, określająca sposób wykonywania „metaforycznej” czynności, jak gdyby odłącza się od dominującego poetyckiego obrazu, ulega autonomizacji. Zmysł dotyku (jego szczególna modalność: „wywołujące” głaskanie) zostaje więc niejako utwierdzony w swej materialności, której jednocześnie - retroaktywnie - udziela swemu przedmiotowi. Zarazem dotyk stanowi tu formę działania w rzeczywistości, której jeszcze nie ma, którą zaledwie zapowiada. Wspomnianej materializacji towarzyszy zatem - by tak rzec - „odsensualnienie”. Sięgając

8 Głębszej interpretacji domaga się, rzecz jasna, zmiana czasu gramatycznego. Być może wartościowy kontekst dla wywoływania obecności przez dotyk stanowią „baśnie mimiczne" Leśmiana. Jak bowiem pisze Andrzej Zawadzki, komentując szkic Mallarmégo Mimique: „Grę artysty mimicznego oraz znak mimiczny cechuje [...] nieustanne operowanie aluzyjnością: zawieszony pomiędzy pragnieniem a spełnieniem, pomiędzy dokonaniem a wspomnieniem, pomiędzy przeszłością a przyszłością, nie dociera on nigdy do znaczenia, do przedmiotu swego przedstawienia, dając jedynie «fałszywy pozór obecności»». Jak zatem w Leśmianowskim Skrzypku opętanym „ruch i gest mimiczny, mające funkcjonować jako synonim przedstawienia autentycznego, mimesis źródłowej, demaskują [...], jednocześnie, samą mimetyczność”. A. Zawadzki, Literatura a myśl słaba, Kraków 2009, s. 382 i 386. W tym kontekście Zawadzki traktuje mim jako potencjalny model języka literatury nowoczesnej (ibidem, s. 393-394). Zob. także: K. Fazan, Leśmianowskie epifanie sceniczne. O baśniach mimicznych [w:] Twórczość Bolesława Leśmiana. Studia i szkice, red. T. Cieślak, B. Stelmaszczyk, Kraków 2000.

9 Mamy zatem do czynienia z rozwojem, realizacją metafory (określenie W.M. Żyrmunskiego; zob. idem, Metafora w twórczości Błoka, przeł. Z. Saloni [w:] Rosyjska szkoła stylistyki, oprac. M.R. Mayenowa, Z. Saloni, Warszawa 1970). Na temat młodopolskiej tendencji do amplifikacji szeregu metaforyzującego i konsekwencji, jakie wynikają z tej metody tworzenia dla wizualności metafory, interesująco pisał Marian Stala. Zob. idem, Metafora w liryce Młodej Polski. Metamorfozy widzenia poetyckiego, Warszawa 1988. W drugiej części pracy (poświęconej metaforom rzeczownikowym) badacz śledzi ewolucję poetyckiej wizualności ku „bezoglądowemu obrazowi poetyckiemu”. Wskazuje także na paradoksy wynikające z nadmiernej obrazowości, gdy metaforyzujące i metaforyzowane mają charakter sensualny, „wyglądowy”. W wierszu Zamyślenie sytuacja jest chyba jeszcze bardziej złożona i paradoksalna: dotyk (gest głaskania) unaocznia bowiem samą unaoczniającą czynność metaforyzowania; jeśli tak, struktura metafory zostaje tu zdekonstruowana - metafora jest zarazem metaforą dotyku/metonimii (którym zawdzięcza swoją możliwość) - i przemieszczona w quasi-fabularny kontekst, który zbliża do siebie wzrok i dotyk. 
w niebyt, dotyk-metafora funkcjonuje jak gdyby poza władzą podmiotu: nie służy bowiem przede wszystkim celom poznawczym ani zmysłowej przyjemności.

W pewien sposób kwestionuje natomiast samą podmiotowość pod-miotu, który zostaje niejako „od wewnątrz” naznaczony innością, wywłaszczony $\mathrm{z}$ istnieniowej pewności ,autochtona w bycie” ${ }^{10}$ : „A nie śpiewam, lecz jeno słowami przez okno / W świat wyglądam, choć nie wiem, kto okno otwiera" [podkr. moje - R.M.]. W perspektywie dalszych interpretacji godne podkreślenia wydaje mi się zwłaszcza to, że przestrzeń zhumanizowana (,wewnętrzna”), która pozwala śpiewać, „słowami przez okno w świat wyglądać”, nie jest wolna od niepokoju niewiedzy. Dotyk, w punkcie wyjścia „posłuszny” intencjom podmiotu, swoją materialnością - a więc jak sądzę: także materialnością metafory, której temat i nośnik splatają się z sobą, wchodzą w relację metonimiczną - zaczyna osłabiać oczy-wistość zaokiennego obrazu, którego możliwość otworzył ${ }^{11}$. Zmysł sięgający ku temu, co nieokreślone, nie jest bowiem podporządkowany percepcji bohatera, nie stanowi jego własności w obu znaczeniach tego słowa.

Inicjuje natomiast proces konstytuowania względnej, niestabilnej - pozostającej zawsze in statu nascendi - tożsamości, której poetycką formułę wyraża pragnienie, by „dożyć” w sobie pieśni, tzn. - jak sądzę - uczynić pieśń

10 Określenie Emmanuela Lévinasa, którego myśl będzie stanowiła dla mnie ważny kontekst w lekturze Zielonej godziny. Odwołanie to pozwoli - jak sądzę - dobitnie wyrazić wątek - dotychczas zaledwie sygnalizowany - etycznego wymiaru poetyckiego dotyku w twórczości Leśmiana.

${ }^{11} \mathrm{Na}$ temat formuły ,widzę poprzez śpiew” (zaczerpniętej $\mathrm{z}$ otwierającego Sad rozstajny wiersza Wieczorem) - oprócz literatury wymienionej w przypisie 6. zob. także: M.P. Markowski, Polska literatura nowoczesna. Leśmian, Schulz, Witkacy, Kraków 2007 (głównie: s. 88-91): „oznacza to, że nie ma podziału na rzeczywistość i poezję, albowiem bez poezji rzeczywistość pozostaje niepoznawalna. Jeszcze inaczej: poezja jest elementarnym warunkiem zjawiania się rzeczywistości. Albo: poezja jest warunkiem sensowności świata" (s. 90). Pełna zgoda, jeśli przyjmiemy - wątek ten rozwinę w dalszej części tekstu - prymat rozumienia (sensu) nad innymi - projektowanymi w poezji Leśmiana - sposobami?/możliwościami? odniesienia do świata. Obserwacja Markowskiego wydaje mi się słuszna właśnie w stosunku do wiersza z Sadu rozstajnego, w którym siła kreacyjna jednoznacznie pochodzi z zewnątrz (,Wiatr się zsunął ze strzechy na gałęzie drzew - / Czy on we mnie tak śpiewa?”) i - być może dzięki temu - zostaje natychmiast zasymilowana w dźwiękowo-wizualnej jedni („Widzę poprzez śpiew, / Jak księżyc wschodzi nad borem”). W Zamyśleniu kierunek „ruchu” tożsamości jest odwrotny (odśrodkowy) - jest ona - jak sądzę - trwale naznaczona innością (w wierszu Wieczorem inność podważa ,jedynie” kulturowe wyznaczniki tożsamości: „Jakże dziwno wymówić własne imię w głos"). Na temat silnego związku widzenia i słyszenia w logofonocentrycznej metafizyce europejskiej zob. np. §7 Bycia $i$ czasu: „W konkretnej realizacji mówienie (umożliwianie widzenia) ma charakter języka, wypowiadania słów. Logos to phoné, a mianowicie phoné meta phantasias, wydawanie dźwięków, w których zawsze coś zostaje ujrzane". M. Heidegger, Bycie i czas, przeł. B. Baran, Warszawa 1994, s. 46. 
częścią własnej egzystencji i jednocześnie wykroczyć poza ową „własność”: „być niewidzialnym, jak ten, co mnie stworzył".

$$
* * *
$$

Cykl-poemat Bolesława Leśmiana Zielona godzina wydaje się - gdy weźmiemy pod uwagę dotychczasowe konkluzje interpretacyjne - materiałem egzemplifikacyjnym dogodnym raczej dla tez o dominacji zmysłu wzroku w poetyckim poliversum późniejszego autora Łąki. Utwory, którym zamierzam poświęcić szczególną uwagę, pozwoliły bowiem interpretować twórczość Leśmiana w kontekście romantycznego z ducha motywu „natury widzącej” i jego modernistycznej - zmierzającej w kierunku osłabienia humanizującej, antropocentrycznej perspektywy - rewizji ${ }^{12}$. Dały też asumpt do próby przeniesienia na grunt poetyckiej ontologii Leśmiana - oddzielonej, rzecz jasna, od swej idealistycznej proweniencji - Berkeleyowskiej zasady: esse-percipi ${ }^{13}$.

Sad rozstajny, debiutancki tom poety, w którego skład wchodzi także interesujący mnie poemat, przynosi jednak również fragmenty wyrażające nieufność wobec percepcji wzrokowej, poświadczające jej niemoc. Sformułowane ustami baśniowej dziewczyny w poemacie Nieznana podróż Sindbada Żeglarza pragnienie, by ,wszystką męką ciała / Odbić się w czyjejś szerokiej źrenicy" (PZ, s. 110), zostaje zrównoważone na przykład w wygłosie wiersza Oczy w niebiosach: „Oczy, na zwiady wysłane w gwiazd roje, / Pochodnie, zgasłe nad marzeń ruczajem - / Oto was z wolna zamykam - sny moje! - / Oczy zamknięte, wspomóżcie się wzajem” (PZ, s. 100). Poznanie poprzez zmysł wzroku zostaje tutaj przyrównane do snu, gdyż w pewien sposób „rozświetla" jedynie podmiotowe marzenia. Inaczej rzecz ujmując: byty jawiące się

12 Zob. np.: U.M. Pilch, Podmiot zamknięty w spojrzeniu. „, Sad rozstajny” Bolestawa Leśmiana [w:] Stulecie „Sadu rozstajnego”, red. U.M. Pilch, M. Stala, Kraków 2014; P. Szwed, Z księgi romantycznych przeczuć. Motyw ,, widzacej natury” w poezji Bolestawa Leśmiana [w:] Leśmian nowoczesny i ponowoczesny, red. B. Grodzki, D. Trześniowski, Radom 2012. Ryszard Nycz podkreśla, że „chwyt «odwzajemnionego widzenia» przedmiotu, mimo formalnego podobieństwa, wykracza jednak zdecydowanie poza tradycyjne konsekwencje zastosowania środków antropomorfizacyjnych. W przypadku Leśmiana nawet je odwraca: obdarzenie natury zdolnością widzenia zmierza nie tyle do jej przekształcenia i zhumanizowania, lecz raczej do eksperymentalnego odwrócenia percepcyjnej perspektywy". R. Nycz, op.cit., s. 123. Badacz odwołuje się w tym kontekście do opisanego przez Waltera Benjamina doświadczenia aury ( $O$ kilku motywach u Baudelaire'a). Wątek ten zamierzam wykorzystać w interpretacji Zielonej godziny, kładąc jednak akcent na nieco inne niż w odczytaniu Nycza aspekty.

13 Zob. M. Podraza-Kwiatkowska, Gdzie umieścić Leśmiana? Próba lokalizacji historycznoliterackiej [w:] Studia o Leśmianie, red. M. Głowiński, J. Sławiński, Warszawa 1971, s. 22. Badaczka sytuuje pragnienie bycia widzianym wobec ontologicznej efemeryczności - naznaczonego nicością - świata implikowanego przez poezję Leśmiana: „istnieć to nic innego, jak być postrzeganym. Jest to zatem jeszcze jeden sposób umocnienia niepewnego bytu". 
w świetle spojrzenia podmiotu istnieją ze względu na ten podmiot, lecz zarazem w radykalnym od niego przestrzennym oddaleniu. Są przed(się)stawione - w sensie Heideggerowskiego Vorstellung - na płaszczyźnie nocnego nieba.

Nie niepewność poznawcza (i ontologiczna) wydaje mi się tu jednak najważniejsza. Jest ona - jak sądzę - zaledwie pochodną niezaspokojonego pragnienia wzajemności. Jak bowiem czytamy w relacjonującym monologu:

My - oczy twoje - widzimy, widzimy

Wszystko, co w niebie pożarem wybucha!

Ale nam przestwór urąga i szydzi

Tych gwiazd migotem i mroków udręką,

Że nas - widzących - nikt zowąd nie widzi [...]

Lecz nikt nam, w mroku wyrosłym, jak kwiaty,

Nie przeciwpowstał - i nie ma nikogo!

I nikt na zwiady w głąb naszą daleką

Nie wyśle strzały ni pary gołębi!...

Wypada zgodzić się z Urszulą Pilch, gdy pisze, iż w przywołanym wierszu „oczy stają się jego [tj. podmiotu - R.M.] esencją, że całe jego istnienie zostaje skupione właśnie w oczach, które nic nie zobaczyły, których nikt i nic nie widzi"14.

Jeśli tak, można by zatem powiedzieć, że wzrokowa percepcja - oddzielona od współdziałania z innymi zmysłami (jedynie oczy mają bowiem „wspomóc się wzajem") - ustanawia nieprzekraczalny - stąd niemoc wzroku - dystans przestrzenny między widzącym a widzianym. Zaryzykuję tu następujące twierdzenie: tylko patrząc w ten właśnie sposób, Leśmianowski bohater widzi wszystko („,o w niebie pożarem wybucha”), lecz widzi jedynie w świetle własnego patrzenia („Dwoje nas w mroku, więc wspólnie się złoćmy / Widzeniem światów, dla których powstajem"); w rezultacie oddalenie od percypowanego świata (którego przeciwieństwem byłaby bliskość) obiektywizuje się w mierzalną odległość (której przeciwieństwo to brak odległości, nieniwelujący jednak oddalenia; funkcjonuje bowiem jako możliwość jedynie w ramach opozycji podmiot - przedmiot). Widzenie - w jego modalności, z jaką mamy do czynienia w wierszu Oczy w niebiosach - zawsze będzie zatem widzeniem tego, co jawi się w dali jako obojętne - i ontologicznie odrębne - wobec (nieobojętnego) patrzącego ${ }^{15}$.

Jakie wnioski jednak wypływają stąd dla interpretacji Zielonej godziny? Najogólniej mówiąc: w przywołanym wierszu podmiot-bohater jest osamotnionym i nieakceptującym swej kondycji bytu odseparowanego podmiotem

14 U.M. Pilch, op.cit., s. 98.

15 Nawiązuję w tym miejscu do rozróżnienia, które zaproponował Martin Heidegger, broniąc pregeometrycznego rozumienia przestrzeni jako przestrzeni sensu: „To, co przestrzennie jest niedostrzegalnie dalekie, może być blisko nas. Mała odległość nie jest już bliskością. Duża odległość nie jest jeszcze dalą". M. Heidegger, Rzecz, przeł. J. Mizera, „Principia” 1996-1997 (t. XVI-XVII), s. 7-8. 
poznania. Poznawanie jest dla niego jak gdyby istnieniową granicą. Jeśli tak, to można powiedzieć, że dominacja zmysłu wzroku, a także - o czym dopiero będzie mowa - swoiste ,przesunięcie” w jego stronę dotyku, są tożsame z dominacją postawy poznawczej, zakorzenionej w dualistycznej ontologii, czy też szerzej: w ontologii w ogóle; ontologię rozumiem tu natomiast jako „postawę" czyniącą bycie bytu swoim punktem wyjścia, widzącą w byciu bytu jego spełnienie. Dlatego też, analizując ingerencję dotyku w „Zwierciadlaną” ontologię Zielonej godziny, zamierzam przeciwstawić się interpretacjom, które traktują zmysł dotyku w poetyckim świecie Leśmiana przede wszystkim jako uprzywilejowany sposób poznania, poznawczego kontaktu z dynamiczną istotą bytu ${ }^{16}$.

Wydaje mi się, że funkcja dotyku w poemacie Zielona godzina jest inna i jeśli można tak powiedzieć - donioślejsza; tym bardziej doniosła, jak sądzę, im bardziej ukryta w metaforycznej „gęstwie” utworu. Chciałbym jednak nie tyle „dekodować” - synestezyjne - metafory, w których obecne jest odniesienie do zmysłu dotyku (wówczas znajdowalibyśmy się nadal w paradygmacie wzroku, „rozświetlania”), ile raczej wskazać, w jaki sposób dotykowi przypisana zostaje funkcja oporu wobec takiego „dekodowania”, a więc: wobec czynności poznawczych, wobec „objaśniania”.

Z konieczności selektywną analizę rozpocznę od trzech cytatów. Pierwszą część poematu otwierają słowa: „Rozechwiały się szumne gałęzi wahadła / Snem trącone! Wybiła Zielona Godzina!” (PZ, s. 31). W części II utworu czytamy natomiast: „Wzdłuż polany przed chwilą wędrowny cień kruka / Przemknął, ledwo ukosem tykając mych brwi” (PZ, s. 32). Część V przynosi potwierdzenie konieczności skierowania interpretacyjnej uwagi na fenomen cienia. Pojawia się on tym razem w kontekście refleksji podmiotu nad własnym ontycznym statusem: „Czylim światów tajemnych zjawionym przedmurzem, / Na które drzewa cień swój kładą nieprzytomnie?” (PZ, s. 35). Zwraca uwagę przede wszystkim to, że mamy tu do czynienia z dotykiem specyficznym: w pierwszym wypadku z dotykiem snu, stanowiącym wpisaną $\mathrm{w}$ utwór jego przyczynę sprawczą; w kolejnych natomiast tym, co dotyka jest cień. Ów dotyk ma zatem „senny”, „,ienisty” charakter - tym samym przeciwstawia się w pewien sposób - zacytujmy trzeci wiersz - ,jasności przestworu”, z którego wygnane zostały na zawsze ,senne gromady powikłanych cieni” (PZ, s. 33).

W tym miejscu chciałbym odejść raz jeszcze od samej Zielonej godziny, by usytuować poemat - jak mniemam: z interpretacyjną korzyścią - w kontekście wierszy zamykających cykl Pieśni mimowolne, a więc bezpośrednio poprzedzających i zarazem zapowiadających interesujący mnie utwór. W wierszu

16 Dla ujęcia interpretacyjnego, od którego zamierzam odejść w niniejszym tekście, modelowy przykład stanowi komentarz Anny Spólnej: „Akcydentalność dotyku jest w nieustannie zmiennym Leśmianowskim świecie jednocześnie jego największą wartością (moment przemiany zyskuje natychmiastowe i namacalne potwierdzenie) oraz największą słabością (rzeczywistość niemal od razu wymyka się poznającemu)”. A. Spólna, Dotyk i niedotykalne w ,Sadzie rozstajnym” Bolestawa Leśmiana [w:] Stulecie..., s. 319. 
Cień tytułowy byt? / fenomen? autonomizuje się, zostaje obdarzony podmiotowością: „Anim patrzał na słońce przez lny, / Anim chodził do boru po sny - / Jenom widział, jak rzucony wzdłuż / Cień mój powstał, by nie upaść już" (s. 25). W dalszych strofach czytamy o podróży Cienia w zaprzeszłość podmiotu, od którego się oddzielił. Przez „zaprzeszłość” rozumiem przeszłość, która nie może zostać przywołana przez „zwykłe” przypomnienie; która wyznacza zatem to, co dla podmiotu niedostępne, lecz stanowiące - by tak rzec - jego część.

Do zastanowienia zmusza jednak - nie tylko ze względu na „cienistość” jeźdźca - status owej podróży. Słusznie zauważa bowiem Barbara Stelmaszczyk, że

[...] oddając głos cieniowi, poeta czyni go instancją nadawczą, która samym aktem wypowiedzi dokonuje przeskoku w pierwotność na „drugą stronę rzeczy”, w metafizyczne wymiary ducha ${ }^{17}$.

Wydaje mi się, że wyznaczony przez badaczkę kierunek myślenia można by jednak zradykalizować. Zauważmy bowiem, iż upodmiotowienie Cienia odbywa się tu przez swoiste ,uwolnienie” zleksykalizowanych metafor ${ }^{18}$. Jest zatem tak, jak gdyby ruch cienia był zarazem ruchem języka; ruch w obrębie języka - tworzyłby, poszerzał i paradoksalnie rozświetlał obszar cienistości. Obecny w języku nadmiar - zaktualizowany - okazuje się tu więc nadmiarem w samym podmiocie (przypomnijmy wnioski z interpretacji Zamyślenia), który naznaczony innością i własnowolnością cienia wykracza poza siebie, mimo że zachowuje względną bierność obserwatora. Nie mamy tu zatem do czynienia z zakładającą aktywność aktualizacją istnieniowej potencji bytu, lecz raczej z jego transformacją, którą wieńczy otwarcie na osobliwą teofanię: „Anim patrzał na słońce przez lny, / Anim chodził do boru po sny - / Jenom widział, jak w wiosenny czas / Z cieniem moim Bóg spotkał się raz..." (PZ, s. 26$)^{19}$.

Należy podkreślić, że wpisanie metafory w metonimiczną sekwencyjność, jej rozwój i realizacja zmierzają w kierunku przywrócenia materialnej gęstości temu, co w pewien sposób służebne, a więc cieniowi jako zjawisku optyczne-

17 B. Stelmaszczyk, Leśmianowski ,cień”- symbol rozszerzonej przestrzeni podmiotu [w:] Stulecie..., s. 79.

18 Na temat fabułotwórczej funkcji Leśmianowskich metafor pisał Michał Głowiński: „metafora nie mieści się w sferze lexis, wchodząc w rejony mythos [...]. Metafory - w sposób mniej lub bardziej bezpośredni - generują fabułę, a także stają się jej elementami. Kształtuje się swego rodzaju jedność między budową metaforyczną a narracją”. M. Głowiński, O języku poetyckim Leśmiana [w:] idem, Zaświat przedstawiony..., s. 97.

19 Co istotne, także w VI części Zielonej godziny Bóg (,spadły z nieba bezwolnie wraz z poranną rosą”) spotykany jest w cieniu, konkretnie: „W parowie, pod leszczyny rozchełstanym cieniem" (PZ, s. 36). O ontologicznej osobliwości Boga (i boga) w poezji Leśmiana zob. M. Nawrocki, Wariacje istnieniowe. O ontologii poetyckiej Bolesława Leśmiana, Tarnów 2009 (głównie rozdział: Coś Bożego). 
mu jedynie ,towarzyszącemu” materialnemu, nieprzejrzystemu bytowi, a także sprozaizowanemu językowi, którego figuralność została podporządkowana funkcji wyrażania sensu, jawiącego się w świadomości. Język-cień, wyzwolony z podległości, działa w analizowanym wierszu jak specyficzny zmysł pozwalający dotrzeć „do baśni, niewidzialnej stąd”, zarazem jednak ustanawiając jej możliwość, profilując ją.

Fenomen „cienistego” języka poezji zbliża się zatem do pewnej modalności dotyku. Nie mam na myśli, rzecz jasna, dotyku uchwytującego (konceptualnego), a więc: służącego realizacji uprzedniego zamysłu poznawczego czy też - przywołajmy raz jeszcze Heideggera - zagarniającego to, co już „rozświetlone" przez podmiot w jego zatroskanym przeglądzie (Umsicht). Modalność dotyku, którą dostrzegam u Leśmiana, byłaby natomiast bliższa dotykowi-pieszczocie w rozumieniu proponowanym przez Emmanuela Lévinasa, tzn. dotykowi, który jeszcze nie wie, czego szuka; który porusza się po omacku (w cieniu, jako cień?) - niejako poza władzą podmiotu ${ }^{20}$. Dotyk stanowi więc swoisty paradygmat dla języka poezji, który odsłania to, co ,niewidzialne stąd", lecz zarazem - by tak rzec - ,wywołując" to, co odsłonięte, pogrąża je we własnym cieniu. Wskazany paradoksalny proces konstytuuje oryginalną strukturę ,widzenia poprzez (śpiew)”, która dynamizuje relację zmysłu wzroku i dotyku.

Chciałbym na chwilę zatrzymać się przy zasygnalizowanym kontekście myśli Lévinasa. Filozoficzne koncepty autora Całości i nieskończoności okażą się - mam taką nadzieję - pomocne w przybliżeniu roli dotyku w kształtowaniu się relacji między podmiotem-bohaterem a światem zewnętrznym w wierszach wchodzących w skład dwóch pierwszych cyklów Sadu rozstajnego. W Pieśni o ptaku i o cieniu anonimowy zmarły (,Ktoś mi obcy, a już - bliski”):

Jakby właśnie szedł z powrotem

Za mnie, za mnie, co - zaklęty -

Róż zrywaniem pochłonięty

Zwlekam wciąż u wnijść tysiąca

Do tych mgieł za mgłą miesiąca,

Zwlekam, w sobie zapodziany,

Zapatrzony, zasłuchany

I tak żądny snów bez celu,

Że mi oto w mym weselu

20 „Antycypacja ujmuje możliwości; to, czego szuka pieszczota, nie mieści się w perspektywie rzeczywistości ujmowalnej [...]. W pieszczocie, która z jednej strony pozostaje stosunkiem zmysłowym, ciało, ukazując się jako erotyczna nagość, ogołaca się z samej swej formy. W cielesnej pieszczocie ciało porzuca status bytu, status jestestwa [...]. Z istoty naruszalna i nienaruszalna Kobiecość, «Wieczna Kobiecość», jest dziewictwem lub nieustannym odnawianiem się dziewictwa, niedotykalnością w samym dotyku rozkoszy, przyszłością w teraźniejszości”. E. Lévinas, Całość i nieskończoność. Esej o zewnętrzności, przeł. M. Kowalska, Warszawa 2002, s. 311. 
Ani nie żal, ani żal

Tych, co za mnie idą w dal!...

(PZ, s. 27-28)

Chciałbym zwrócić uwage przede wszystkim na sposób istnienia Leśmianowskiego bohatera. Jest on „w sobie zapodziany”, jego bycie cechuje zwłoka (opóźnienie powrotu) czy też, formułując rzecz radykalniej i chyba także trafniej, zwłoka wręcz funduje jego istnienie, jest jak gdyby samym jego istnieniem. Warto nadmienić, że w wygłosie całego tomu - w ostatniej części poematu Nieznana podróż Sindbada Żeglarza - życie zostało określone jako „miłosna zwłoka / Na piersi ziemi”. Mówiąc językiem Lévinasa, podmiot-bohater wiersza jest bytem-istniejącym-przeciw-śmierci. Jego bycie odracza to, nieuchronne, jest samym tym odroczeniem. Konstytuuje się zatem w czasowym dystansie wobec teleologii bytu przyrodniczego; człowiek jest bowiem bytem, który zawsze jeszcze ma czas; jest ,żądny snów bez celu”. Należy wskazać, iż ów wymiar temporalny ujawnia się jako ,pochłonięcie”, ,zapodzianie", a więc poprzez zmysłowe - to także termin z leksykonu Lévinasa - „rozkoszowanie się” światem. Jak pisze filozof:

Rzeczy, którymi żyjemy, nie są narzędziami ani nawet rzeczami poręcznymi w Heideggerowskim sensie terminu [...]. Co więcej, podczas gdy sięganie po narzędzie zakłada celowość i oznacza naszą zależność od czegoś innego, życie czymś wyraża niezależność używania i szczęścia, które jest źródłową postacią wszelkiej niezależności [...]. Rozkoszowanie jest takim właśnie żywieniem się aktu samą swą aktywnością ${ }^{21}$.

Sięgnięcie ku światu - ,zrywanie róż” w wypadku analizowanego wiersza - zawiera zatem moment zatrzymania się w świecie, opóźnienia powrotu do podmiotowego zamknięcia; ,rozkoszować się” znaczy więc nawiązać z bytem relację, która pozwala dotknąć jego materialności, która - tym samym - odracza powrót do podmiotowego świata teleologii sensu, troski o własne bycie, czyniącej napotkany byt jego sensownym przedstawieniem. ,Zapatrzenie" i ,zasłuchanie" są tu - jak sądzę - wtórne wobec, ustanawiającego ową relację, dotyku; stanowią jego swoiste modalności.

W kontekście wcześniej rozpatrywanego wiersza Cień zasadne wydaje mi się także przypuszczenie, że wspomniany powrót do samego siebie można interpretować również $\mathrm{w}$ odniesieniu do metaforyczności czy figuralności języka poezji. Realizowana metafora wpisana w- i ustanawiająca fabularną sekwencję, w pewien sposób odwleka bowiem, czy wręcz uniemożliwia, powrót do swego macierzystego sensu, a więc do tego, co już znane; co jawi się świadomości wyraźnie - w jej własnym świetle. Przypomnijmy tu negatywny wariant tego paradygmatu, który - jak sądzę - stanowi wiersz Oczy w niebiosach. Metafora oczu wysłanych „w głąb oćmy nocnego nieba” powraca bowiem - w zakończeniu wiersza - do punktu wyjścia. Innymi słowy: poetycka „fabuła” zostaje podporządkowana oczy-wistemu wyjściowemu sensowi

$21 \quad$ Ibidem, s. 118. 
metafory. Inaczej mówiąc: metafora jest tu służebna wobec wyrażanego przez nią sensu; w rezultacie ów powrót, podkreślany kolistą konstrukcją wiersza, jest zarazem powrotem sensu do samego siebie i podmiotu do własnej - ograniczonej tym sensem - esencji, którą nieprzypadkowo - przypomnijmy trafny komentarz Urszuli Pilch - stanowią właśnie oczy ${ }^{22}$.

W nawiązaniu do sformułowanych wniosków chciałbym zaproponować zarys interpretacji działania dotyku w poemacie Zielona godzina. Uwagę skoncentruję między innymi na V części utworu, w której mamy do czynienia z - jak się wydaje ,izomorficzną” wobec fabuły całego poematu - relacją z kontaktu człowieka i bytu wobec niego zewnętrznego, a także radykalnie odmiennego zarazem:

Na rękach niosę strumień, potrząsany płaczem.

I uśmiechem go poję i do snu kołyszę,

By go złożyć pod skałą - na trawie - na mchu.

Brzozy, nagle od ziemi oderwane łona,

Idą za mną, by drogę śpiewaniem mi skrócić

I - marzeń dźwigaczowi - leśnych przydać sił...

(PZ, s. 35)

Jak jednak rozumieć - w kontekście dotychczasowych wniosków - „dźwiganie marzeń" przez bohatera? Wydaje mi się, że strumień został tu w pewien sposób wydobyty z całości bytu. To, co umożliwia kontakt z nim, jest także tożsame $\mathrm{z}$ jego, rozumianą po Bergsonowsku, percepcją, a więc percepcją-działaniem, stanowiącą miarę możliwego oddziaływania człowieka na percypowany byt ${ }^{23}$. Poznawczo-manipulatywne „uchwycenie” jest zatem ruchem skierowanym przeciw teleologii i całościowości natury. Zarazem strumień zostaje tu zantropomorfizowany („Na rękach niosę strumień, potrząsany płaczem”). Dokonujące się w ten sposób zawłaszczenie staje się jednak punktem wyjścia sekwencyjnego rozwoju metafory, zarazem - retroaktywnie - ów punkt wyjścia ustanawiającej: jeżeli strumień płacze, można go utulić; stąd

22 W tym kontekście godne uwagi, że w (najprawdopodobniej) późnym wierszu (Niegdyś dom mój ochoczy $i$ świat za dąbrowa), ,powrót do siebie” został utożsamiony ze śmiercią, która nie znosi jednak ontycznego? / tożsamościowego? konfliktu: „I zgaduję, że z płaczem, po własnym pogrzebie, / W opuszczoną bezdomność powracam do siebie” (PZ, s. 477).

23 „Jednakże, jeżeli układ nerwowy w całym świecie zwierzęcym jest skonstruowany do działania coraz to mniej koniecznego, to czy nie należy sądzić, że również percepcja, której rozwój dostosowuje się do stopnia rozwoju układu nerwowego, jest całkowicie ukierunkowana na działanie, a nie na czyste poznanie?" - pyta Bergson w Materii i pamięci i całością swojego dzieła odpowiada twierdząco. Filozof łączy także wątek ten wykorzystam w dalszych analizach - percepcję i pamięć: „Trwająca w ułamku sekundy najkrótsza możliwa percepcja światła mieści tryliony wibracji, z których pierwsza od ostatniej jest oddzielona przez interwał bardzo podzielony. Wasza percepcja, choćby najkrótsza, polega więc na nieprzeliczalnym mnóstwie przypomnianych elementów, prawdę mówiąc, każda percepcja jest już pamięcią". H. Bergson, Materia i pamięć. Esej o stosunku ciała do ducha, przeł. R. Weksler-Waszkinel, Kraków 2006, s. 25 i 120. 
początkowe - antropomorfizujące - „wyniesienie” nabiera nieco innego charakteru, zostaje osłabione. Swoiste „,przytrzymanie” strumienia, pozwalające doświadczyć jego „strumienistej” materialności, jest tu przygotowane i niejako odgrywane przez ruch odwleczenia spełnienia sensu organizującej fragment figury.

Dotyk nie tylko uchwytujący, lecz i poszukujący innego bytu, tzn. dotyk, który jeszcze nie wie, czego szuka, zdaje się w poemacie Zielona godzina nieodłączny od wskazanej przeze mnie poetyckiej strategii. Język nabiera tu zatem charakteru dotyku, który jest jednak - jako utrwalenie marzenia, ułudy, pragnienia - zaledwie własną antycypacją. Swoista „dotykalność” poetyckiej mowy wprowadza w bliskość to, co odległe - w sensie przestrzennym i ontologicznym. Dlatego też w Zielonej godzinie to strumień, ruczaj (to odwrotność kierunku metaforyzacji, z jaką mamy do czynienia w wierszu Oczy w niebiosach; „ruczaj marzeń” jest bowiem ruczajem pozbawionym autonomii, a więc zarazem: obcym, odległym, niezdolnym do odbicia tego, co pozapodmiotowe) w „srebrnym obrębie tai niebo” (cz. III), a także przywrócony ziemi „Za kres boru wybiega, w nieskończoność polną" (cz. V).

Należy dodać - to wątek ufundowany w Leśmianowskich paradoksach przestrzennych - że językowy dotyk jako własna antycypacja w interesujący sposób wzbogaca zmysł wzroku, otwiera przestrzeń widzenia, które nie zawłaszcza i zarazem nie „upada” w wymiar podmiotowej projekcji. Także w tym kontekście uzasadnione wydaje mi się przywołanie doświadczenia aury:

Czymże właściwie jest aura? To osobliwe przędziwo z przestrzeni i czasu: wyjątkowe zjawisko dali, niezależnie od tego, jak jest bliskie. Widoczna na horyzoncie podczas odpoczynku na zboczu góry niedzielnym popołudniem, podążanie wzrokiem za gałęzią rzucającą cień na odpoczywającego - to znaczy chłonięcie aury tych gór, tej gałęzi ${ }^{24}$.

Drugi z przywołanych przez Benjamina obrazów (gałąź rzucająca cień na człowieka) przywodzi na myśl stosowaną przez Leśmiana w Zielonej godzinie strategię osłabiania oczy-wistości relacji w zgeometryzowanej przestrzeni (jak w X wierszu cyklu, w którym cień upada „, przesianych przez liście zaświatów" ${ }^{25}$. Skłania także do skonfrontowania z tą właśnie perspektywą

24 W. Benjamin, Dzieło sztuki w dobie jego technicznej reprodukcji [w:] idem, Twórca jako wytwórca. Eseje i rozprawy, przeł. R. Reszke, Warszawa 2011, s. 29.

25 Jak trafnie komentuje Michał Głowiński: „Przestrzeń to jakby kubistycznie kształtowana, jeden jej niewielki wycinek postrzega się z rozmaitych perspektyw, to, co dalekie, staje się bliskie, to, co bliskie - dalekie. Perspektywy te się nie tylko nie wykluczają, ale - przeciwnie - nakładają na siebie". M. Głowiński, Zaświat przedstawiony, s. 293. O podobnym efekcie w twórczości Błoka - stanowiącym konsekwencję pracy metafory - pisze Wiktor Żyrmunski: „Aktualizując poglądowe przedstawienie, obraz wzrokowy, ukryty potencjalnie w każdej oddzielnej części konstrukcji językowej, otrzymuje [Błok R.M.] złożoną całość - z logicznego punktu widzenia wewnętrznie sprzeczną, irracjonalną". W.M. Żyrmunski, op.cit., s. 326. 
paradoksu sformułowanego w wygłosie czwartej części poematu: „Lecz choćbyś do mej piersi przywarła się blisko, / Zawsze będę cię widział cudownie daleką - / Przez ukryty w mych oczach, nie znany ci las!" (PZ, s. 34).

We wspomnianym utworze w sposób najbardziej wyrazisty - jak sądzę - ukazana została interakcja wzroku i dotyku, a także ich uwikłanie - rodzaj dwustronnego uwarunkowania - w tropologiczną strukturę wiersza. Już pierwsze wersy, wprowadzające w wymiar sensualny, nie są wolne od retorycznego napięcia:

Dziewczyno, nim się w mojej odbijesz źrenicy,

Musisz przebrnąć splątane zieloności zwoje,

Co od dawna mych oczu zaprószyły głąb.

Synestezyjna metafora „odbicia się w czyjejś źrenicy” traci - jako część apostrofy - znaczeniową przejrzystość. Sytuacja ma tu - jak sądzę - charakter aporetyczny: jeśli zgodzimy się na sprowadzenie przytoczonej metafory do jej „właściwego” sensu (odbić się w czyjejś źrenicy = zostać przez kogoś zobaczonym), znaczeniowego nadmiaru nabierze inicjalny wołacz. Byłoby bowiem tak, jak gdyby podmiot zwracał się do dziewczyny jeszcze nigdy przez niego niewidzianej. Zalążkowa dialogiczność realizowałaby się zatem jako język - nieprzechodni, materialny - niejako „wywołujący” nieobecną (nieistniejącą?) dziewczynę.

Owego „wywoływania” nie należy jednak redukować do symbolistycznego kontekstu sprawczego potencjału mowy poetyckiej. Analizowany wers cechuje natomiast - jak mi się wydaje - swoista wzrokowo-dotykowa „ekonomia". Proste odczytanie metafory, wpisujące się w paradygmat jasnego widzenia sensu, a więc - tym samym - pozbawienie jej materialności signifiant, odbywa się kosztem obecnego w niej odniesienia do zmysłu dotyku. Zarazem językowa materialność ulega w ten sposób przemieszczeniu na początek wersu i wiersza. Materialność ta jest jednak - „genetycznie” - zależna od interpretacyjnie „wypartego” zmysłu. W tym kontekście opór znaczącego byłby więc tożsamy z modalnością dotyku niejako muskającego to, czego (jeszcze) nie ma, lub - co zapewne bardziej umotywowane wobec całości utworu z rodzajem dotyku-pieszczoty, który nie niszczy aury - tj. dali w bliskości, nieobecności w obecności - jawiącego się w jego zasięgu bytu.

Sformułowane wnioski chciałbym skonfrontować z frapującym problemem sposobu istnienia lasu zapośredniczającego w wierszu relację dwojga. Niewątpliwie ma on byt językowy, stanowiący konsekwencję rozwoju inicjalnej metafory („Leśno tam [w oczach podmiotu - R.M.] i cieniście, jak w owej krynicy, / Gdzie drzew wierzchy tkwią na dnie. Nie patrz w oczy moje, / Bo twą postać przesłoni [podkr. moje-R.M.] pierwszy z brzegu dąb!..." - czytamy w drugiej strofie). „Wewnątrzwierszowa”, sformułowana wprost przez osobę mówiącą, motywacja obecności lasu między kochankami wiąże się natomiast z uobecniającym mechanizmem pamięci. W gromadzeniu doświadczeń wzrok spełniał funkcję „uchwytującą”, był więc bliski dotykowi, który został tu jed- 
nak dialektycznie „,wchłonięty”, podporządkowany podmiotowo-przedmiotowemu dualizmowi: „Długo one - te oczy - zbłąkane wśród jarów - / Zbierały kwiaty żywe i śmiertelne zioła, / Zważając na motyli dookolny tan".

Działanie to - mimo pozorów wykraczania „na zewnątrz” - wzmacnia podmiotową perspektywę, fundowaną na trosce o własne bycie: „I nie wiem, czy śmierć kiedyś udźwignąć podoła / Ducha, jagód purpurą przeciążony dzban”. Jeśli uznamy śmierć za apogeum przemocy wywieranej przez naturę, pamięć funkcjonuje tu jako gwarant ludzkiej wolności. Tak sformułowany wniosek pozwala spojrzeć na wiersz przez pryzmat Bergsonowskiej koncepcji pamięci. Zdaniem filozofa, pamięć pozwala zachować dystans wobec teraźniejszości, a więc wobec tego, co wymaga automatycznej, odruchowej reakcji. Dzięki niej możliwe są „,ruchy, które przejdą przez otwory sieci naturalnej konieczności”26. Obrazy z przeszłości - „wdzierające się” w teraźniejszość, współkształtujące aktualną percepcję - wywołane przez określony bodziec, „oswajają" go, podporządkowują - na zasadzie podobieństwa - przeszłemu doświadczeniu ${ }^{27}$.

Układ percepcja-pamięć użytkowa funkcjonuje zatem w sposób zbliżony do mechanizmu metafory. W wierszu fakt ten egzemplifikują na przykład ogólne, związane z „samozachowaniem”, rozróżniające kategorie („kwiaty żywe i śmiertelne zioła”), a także - pośrednio - służebność czynności „wzrokowego" zbierania - na poziomie retorycznym: wobec sensu, w planie „fabularnym" natomiast: wobec podmiotowej autonomii ,ja" mówiącego. Tak sprofilowana relacja zostaje jednak - by tak rzec - „rozchwiana” niczym „szumne gałęzi wahadła”. Inicjalny „dotykający”, tj. przejmujący energię retorycznie stłumionego dotyku, wołacz spełnia bowiem - jak sądzę - funkcję bodźca, który niczym dotyk, a więc zmysł najbardziej bezpośredni, „symetryczny”, wymusza pewną reakcję, która jednak - paradoksalnie - aktualizuje pamięć niezaangażowaną w praktyczne działanie. Ma to - rzecz jasna - przełożenie na plan figuralny: metafora „zbierania wzrokiem” zostaje na tej drodze udosłowniona ${ }^{28}$.

Energia pragnienia - przejawiająca się poprzez metaforyczny nadmiar, swoiste dotknięcie językiem - przełamuje zatem podmiotową immanencję. Sam bohater wiersza podkreśla unikatowość tego wydarzenia, jego „niespodzianość” : „Że też tymi oczami, gdzie las ma schronisko, / Zdołałem postrzec ciebie - w twej chacie za rzeką”. Ową „niespodzianość” można - jak mniemam - tłumaczyć osobliwą koincydencją wzroku i dotyku, zmysłów „,wple-

26 H. Bergson, op.cit., s. 166.

27 Pamięć użytkowa, motoryczna, przejawia się przez ,percepcję podobieństw”. Ibidem, s. 125 .

28 Innymi słowy: dotyk w jego poetyckiej modalności byłby zmysłem paradoksalnie łączącym bliskość i dystans, czyniącym możliwy paradoks „cudownego oddalenia” mimo przestrzennej bliskości. Owo oddalenie jest jednak - na prawach podtrzymywanego (przez dotyk-metaforę) paradoksu - także... bliskością. 
cionych" przez Leśmiana w figuralny wymiar utworu i zarazem trwale tym zabiegiem naznaczonych.

Jak zatem - w świetle powyższych interpretacji - jawi się kwestia potencjalnej taktylności poezji? Wydaje mi się, że poezja Bolesława Leśmiana pozwala rzetelnie rozważyć możliwości, jakie stwarza ujęcie poetyki tekstu w perspektywie dotyku. Analizowane retoryczne strategie autora Sadu rozstajnego zmierzają bowiem - jak sądzę - ku takiej formie ,rozluźnienia tkanki rzeczywistości”"29, która pozwoliłaby traktować język poetycki jako niezawłaszczającą, etycznie wartościową modalność wspomnianego zmysłu. Jeśli tak, sama poetycka ,złuda” zyskałaby „namacalność”, wpisując się w sensualną rzeczywistość i zarazem wzbogacając ją o kolejny - ulotny, lecz niemniej rzeczywisty - wymiar.

\section{Bibliografia}

Benjamin W., Dzieło sztuki w dobie jego technicznej reprodukcji [w:] idem, Twórca jako wytwórca. Eseje i rozprawy, przeł. R. Reszke, Warszawa 2011.

Benjamin W., O kilku motywach u Baudelaire'a [w:] idem, Konstelacje. Wybór tekstów, przeł. A. Lipszyc, A. Wołkowicz, Kraków 2012.

Bergson H., Materia i pamięć. Esej o stosunku ciała do ducha, przeł. R. Weksler-Waszkinel, Kraków 2006.

Dziadek A., Projekt krytyki somatycznej, Warszawa 2014.

Fazan K., Leśmianowskie epifanie sceniczne. O baśniach mimicznych [w:] Twórczość Bolesława Leśmiana. Studia i szkice, red. T. Cieślak, B. Stelmaszczyk, Kraków 2000.

Głowiński M., Ojęzyku poetyckim Leśmiana [w:] idem, Zaświat przedstawiony. Szkice o poezji Bolestawa Leśmiana, Kraków 1998.

Głowiński M., Słowo i pieśń (Leśmiana poezja o poezji) [w:] idem, Zaświat przedstawiony. Szkice o poezji Bolesława Leśmiana, Kraków 1998.

Głowiński M., Zaświat przedstawiony [w:] idem, Zaświat przedstawiony. Szkice o poezji Bolesława Leśmiana, Kraków 1998.

Heidegger M., Bycie i czas, przeł. B. Baran, Warszawa 1994.

Heidegger M., Rzecz, przeł. J. Mizera, „Principia” 1996-1997 (t. XVI-XVII).

Leśmian B., Poezje zebrane, Warszawa 2010.

29 Sformułowanie z listu Brunona Schulza do Witkacego (zob. B. Schulz, Księga listów, oprac. J. Ficowski, Gdańsk 2002, s. 102), wykorzystane przez Krzysztofa Stalę śledzącego rodzaje i funkcje metaforyzacji w dziele autora Sklepów cynamonowych. Podstawowe założenie Stali o ,podwójnym ruchu wewnątrz metafory: z jednej strony destrukcji, dekompozycji rzeczywistości, z drugiej - restrukturalizacji, polegającej na odtworzeniu nowej spójności świata, niejako z wnętrza metafory", może zostać - jak sądzę - z zyskiem poznawczym przeniesione na grunt badań nad twórczością Leśmiana. Zob. K. Stala, $N a$ marginesach rzeczywistości. O paradoksach przedstawiania w twórczości Brunona Schul$z a$, Warszawa 1995, s. 153. 
Lévinas E., Całość i nieskończoność. Esej o zewnętrzności, przeł. M. Kowalska, Warszawa 2002.

Łapiński Z., Metafizyka Leśmiana [w:] Studia o Leśmianie, red. M. Głowiński, J. Sławiński, Warszawa 1971.

Łebkowska A., Jak ucieleśnić ciało: o jednym z dylematów somatopoetyki, „Teksty Drugie" 2014, nr 4.

Markowski M.P., Polska literatura nowoczesna. Leśmian, Schulz, Witkacy, Kraków 2007.

Miłosz Cz., Wiersze wszystkie, Kraków 2011.

Nawrocki M., Wariacje istnieniowe. O ontologii poetyckiej Bolesława Leśmiana, Tarnów 2009.

Nycz R., ,,Stowami... w świat wygladam”. Bolestawa Leśmiana poezja nowoczesna [w:] idem, Literatura jako trop rzeczywistości. Poetyka epifanii w nowoczesnej literaturze polskiej, Kraków 2012.

Pilch U.M., Podmiot zamknięty w spojrzeniu. ,,Sad rozstajny” Bolesława Leśmiana [w:] Stulecie „,Sadu rozstajnego”, red. U.M. Pilch, M. Stala, Kraków 2014.

Podraza-Kwiatkowska M., Gdzie umieścić Leśmiana? Próba lokalizacji historycznoliterackiej [w:] Studia o Leśmianie, red. M. Głowiński, J. Sławiński, Warszawa 1971.

Przymuszała B., Szukanie dotyku: problematyka ciała w polskiej poezji współczesnej, Kraków 2006.

Schulz B., Ksiega listów, oprac. J. Ficowski, Gdańsk 2002.

Spólna A., Dotyk i niedotykalne w ,, Sadzie rozstajnym” Bolesława Leśmiana [w:] Stulecie „, Sadu rozstajnego”, red. U.M. Pilch, M. Stala, Kraków 2014.

Stala K., Na marginesach rzeczywistości. O paradoksach przedstawiania w twórczości Brunona Schulza, Warszawa 1995.

Stala M., Metafora w liryce Młodej Polski. Metamorfozy widzenia poetyckiego, Warszawa 1988.

Stelmaszczyk B., Leśmianowski „cień” - symbol rozszerzonej przestrzeni podmiotu [w:] Stulecie ,Sadu rozstajnego”, red. U.M. Pilch, M. Stala, Kraków 2014.

Szwed P., Z księgi romantycznych przeczuć. Motyw ,, widzacej natury” w poezji Bolesława Leśmiana [w:] Leśmian nowoczesny i ponowoczesny, red. B. Grodzki, D. Trześniowski, Radom 2012.

Winiecka E., Z wnętrza dystansu. Leśmian - Karpowicz - Białoszewski-Miłobędzka, Poznań 2012.

Zawadzki A., Literatura a myśl słaba, Kraków 2009.

Zięba J., Pieniadz i słowo. Nowoczesne paradoksy Leśmianowskiego języka poetyckiego, „Teksty Drugie” 2010, nr 6.

Żyrmunski W.M., Metafora w twórczości Błoka, przeł. Z. Saloni [w:] Rosyjska szkoła stylistyki, oprac. M.R. Mayenowa, Z. Saloni, Warszawa 1970. 